\title{
Did ISI fail and is neoliberalism the answer for Latin America? Re-assessing common wisdom regarding economic policies in the region
}

ANIL HIRA*

The second phase of Import Substituting Industrialization, commonly known as ISI2, involved the move in Latin America to "heavy" industrialization, from around 1950-80. This period of economic history has been reviled on both the Left and the Right as being one of either heightened dependency or one demonstrating the clear failure of state intervention in the economy. In this research note, a basic statistical analysis is used to back up other descriptive claims that the ISI2 period was rather one of mixed success, with macroeconomic volatility accompanying great progress in GDP and manufacturing growth. In a sense, the ISI 2 period succeeded in industrializing the large economies of the period, and contrasts favorably with the record of the succeeding paradigm of neoliberalism. This research note seeks to raise questions about the way we look at the historical period of ISI2, and suggests that a more open-minded perspective could lead to a more effective and sustainable political economy paradigm for the region in the future.

Key-words: Neoliberalism; Import substituting industrialization

JEL Classification: B20; N16; O40

\section{INTRODUCTION}

General reviews of Latin American economic history document well the stages of industrialization. ${ }^{1}$ Industrialization in Latin America, in the form of basic consumer goods import substitution, was necessitated by the Great Depression and then by the two World Wars, which ended the system of selling commodity exports in return for manufactured goods dating back to colonial times. However,

\footnotetext{
* Department of Political Science \& Latin American Studies, Simon Fraser University, Burnaby, Canada. E-mail: ahira@sfu.ca. Submitted: June 2005; accepted: July 2006.

${ }^{1}$ Thorp, 1998.
} 
a variety of factors detailed in Latin American histories, including the influx of European immigrants, incipient industrialization, and changes within the military, were reflected in changes in politics. The rise of the populist dictators like Cardenas in Mexico, Peron in Argentina, and Vargas in Brazil, marked a period of nationalism that was partly enabled by the US's desire to maintain allies, even unpleasant ones, during World War II and the Cold War. ${ }^{2}$ The military regimes in Latin America moved from creating political stability to self-avowed positions of leadership in their conception of national development. That conception was based, quite naturally, on the US and reconstructing Europe as models, thus industrialization was considered an integral process of development. The military regimes therefore led the charge into the second stage of ISI (import substituting industrialization), namely that of high value-added manufactures, often initiated by the development of state-owned enterprises in heavy and chemical industries.

The ISI2 period of approximately 1950-1980 was under siege from both the left and the right. Dependency theorists such as Gunder Frank and Teodoro dos Santos suggested that ISI2 was simply a new form of dependency and imperialism. ${ }^{3}$ The economic dependency of colonial times was described as exporting raw materials in exchange for finished products. Under ISI2, according to these arguments, the dependency was merely transformed into an exchange of raw materials for semi-finished goods. Dependency theorists suggest that industrialized Latin America is now in the semi-periphery, used as a platform for multinational corporations who wish to exploit its cheap labor. ISI2 also exacerbated financial dependency according to them, as illustrated by the debt crisis of the 1980s. In short, ISI2 did nothing to improve international and national class polarization based on the mode of production (specialization of each geographic area in the international production process); in fact, industrialization exacerbated differences both internationally between Latin America and the North, and within Latin American countries. ${ }^{4} \mathrm{~A}$ different strain of the attack on ISI 2 comes from associating it with the political repression of the military regimes, best illustrated by Guillermo O'Donnell's theory of the bureaucratic-authoritarian regime, as one in which the military must intervene to hold down labour costs and related political mobilization as a part of entering late and limited industrialization. ${ }^{5}$

ISI2 has also received a black eye from mainstream, neoliberal economists. By the early 1980s, even CEPAL, the home of Raúl Prebisch and the structuralist

\footnotetext{
${ }^{2}$ For instance, it is well known that Brazil's first steel plant at Volta Redonda, was built with US technology as a form of quid pro quo for Vargas' support of the allies in WWII. Similarly, US reaction to Mexican nationalization of petroleum reserves was stultified by the need to maintain Mexico on side during the WWII. Argentina's status of neutrality during WWII put it at odds with the US, however, during the Cold War, and the military's importance in holding off a Cuban style revolution made them allies again.

${ }^{3}$ Grosfoguel (2000). See also the discussion by Cardoso (1977), esp. 10-11.

${ }^{4}$ Weaver (2000).

${ }^{5}$ O'Donnell (1978).
} 
thought behind ISI2 policies, had turned against it. ${ }^{6}$ Sebastian Edwards, a proponent of the neoliberal policies of the Washington Consensus, provides perhaps the best summary about why ISI is considered an abysmal failure:

- First, excessive protectionism and generalized government controls greatly encouraged rent-seeking activities, and created a rigid economic structure unable to react rapidly to changing world economic conditions.

- Second, in many countries the combination of increasing burdens on public sector budgets and inefficient tax systems reduced government's ability to provide social services efficiently, and generated an increasing degree of inequality. By the late 1970s, the region had, by far, the most unequal distribution of income in the world.

- Third, as a result of weak public finance structures, more and more countries were forced to rely on inflationary financing as a way to bridge government expenditures and revenues.

- And fourth, as a consequence of the inward-looking strategy, exports were greatly discouraged, barely growing between 1960 and 1980 .

To these problems, Edwards adds a low return on investment. According to him, the debt crisis beginning in the 1980s revealed the fragility of the ISI2 system. Edwards then goes on to explore the success of the neoliberal reforms. ${ }^{7}$ Even most former cepalinos agree that the parallel balance of payments, exchange rate, inflationary, and anti-agricultural biases were evidence that ISI as practiced was unsustainable. $^{8}$

Could ISI have been fixed? As far back as early 1960s, CEPAL was urging important modifications such as exporting manufactures, reducing urban bias, and increasing integration with other Latin American countries. ${ }^{9}$ In practice, the ISI 2 model was pushed out by the oil price and debt crises by the 1980 s, when the present paradigmatic shift to neoliberalism was consummated. ${ }^{10}$ Though dissenting voices were available, they have largely been ignored. A key voice in the early 1980s was Fernando Fajnzylber of the UN ECLAC, who sought to popularize the ideas behind East Asian development. ${ }^{11}$ Fajnzylber called for the restoration of macroeconomic stability through fiscal balance and control of

\footnotetext{
${ }^{6}$ Author, 1998.

${ }^{7}$ Edwards (1995, pp. 1-5).

${ }^{8}$ Iglesias.

${ }^{9}$ Author (1998) summarizes these, as well as the reasons for ignoring them. Albert O. Hirschman discussed the need for major adjustments in a seminal article in 1968; see Hirschman, 1968. See also Thiesenhusen (1972) and Baer (1972).

${ }^{10}$ It is worth noting that the Fed's decision to whip inflation through massive interest rate hikes in 1982 had much to do with precipitating the downfall of ISI. While Chile instituted neoliberalism in the 1970s, and Argentina began attempting macroeconomic stabilization policies inspired on neoliberalism from 1976, as a whole the region did not embrace the new paradigm until the 1980s. See Hira (1998).

${ }^{11}$ See Fajnzylber (1990, esp. 183-190).
} 
inflation as well as an active state engaged in improving the productivity. Productivity improvements could include investment in physical and human capital; moving strategically from natural-resource based 'nonrenewable income' sources to renewable ones in agriculture and manufacturing; emphasizing continual improvements in technological capacity; embracing the idea of competing with the international economy; developing a competent public sector that enhances international competitiveness and works cooperatively in pacts between state, business, and labour. Most importantly, he suggested that equity and productivity are not only compatible but mutually necessary. Fajnzylber was a visionary in the vein of Raúl Prebisch, however his ideas did not fit with the context of the time. Unfortunately, these competing voices were drowned out by the sea of literature espousing neoliberalism.

It is equally interesting, if not unexpected, historical development that neoliberalism has also sparked polarizing debates about its performance. Beyond the expected dependency critics on the one hand, ${ }^{12}$ and the cheerleaders among mainstream economists and international institutions on the other, ${ }^{13}$ there are also an emerging set of new empirically-based critiques of performance under neoliberalism. Lance Taylor summarizes some of these nicely as: ${ }^{14}$

- Badly unbalanced relative prices structures leading to high domestic interest rates, highly appreciated real exchange rates, reductions in the purchasing power of the real wage combined with labor cost increases in the traded goods sector.

- Financial instability, often centred around the stock markets, which were expanded to accompany public enterprise privatization. This fragility is exacerbated by violent movements of external capital in and out of national economies via liberalized capital accounts.

- Visibly increased corruption, even though liberalization is supposed to abolish unproductive income flows generated by state intervention and associated rent-seeking, while privatization is supposed to level financial playing fields by creating competitive capital markets. Indeed, competition may have weakened in manufacturing sectors in which concentration of ownership has gone up in the wake of privatization.

- Mixed effects at best in stimulating production in key agricultural and manufacturing sectors.

- Rising unemployment and/or regressive income redistribution and deeper poverty induced by recently falling growth rates.

We think it is high time to synthesize a more comprehensive, empiricallybased view of the performance of ISI2, comparing it with neoliberalism. This

\footnotetext{
${ }^{12}$ For an overview of anti-neoliberalism from the left, see Ellner (2004).

${ }^{13}$ Edwards and virtually any World Bank publication from the early 1990s.

${ }^{14}$ Lance Taylor (1999, pg. 9).
} 
exercise will give us a more accurate view about Latin America's policy choices over the last 5 decades.

\section{WAS ISI2 SUCCESSFUL IN LATIN AMERICA?}

Did ISI really fail in Latin America? As we shall see in the next section, by any number of measures Latin America did industrialize. The key question may be more along the lines of the quality and type of industrialization that took place, a question to which we shall return later. The caricature that critics of IP make of its "clear failure" in Latin America is presenting the image of the overblown and inefficient state-owned enterprise that is rife with corruption, political patronage, and cronyism, effectively punishing consumers for the political and economic gain of a small minority. It's unfortunate that this caricature seems to pervade much of the economic analysis of Latin America's recent history, particularly by the international institutions that most affect external financing for the region. As Cárdenas, Ocampo, and Thorp (2000, p.31) state in their definitive historical study of the ISI period in Latin America:

The 'Washington consensus' view of import substitution industrialization as a massive detour, a 'policy mistake' which could somehow have been avoided, is grossly ahistorical and inappropriate... Its implicit view of the collapse of state-led industrialization as a manifestation of its own inadequacies is as inadequate as the Marxist prescription that capitalism would collapse because of its own internal contradictions... Pure economic explanations are an inadequate route to understand both the excesses of state-led industrialization and also its demise.

The stereotype suffers from at least two basic flaws. First, it is based on prejudice, rather than analysis. There were a vast array of instruments used in industrial policy, and the effects of these are impossible to separate out, given the limited number of national cases and the intertwining of the instruments and a wide variety of constantly changing local, domestic, and international economic conditions and policies. Second, there are an equally wide variety of experiences and types of arrangements with state-owned enterprises, not only in Latin America, but internationally. ${ }^{15}$ Petrobrás, for example, while widely criticized, is a widely traded and successful state-owned company. Indeed, most of the major international companies were either former state-owned companies, such as

\footnotetext{
${ }^{15}$ The variations are enormous over time and space and include differences in ownership of elements of the productive chain; subcontracting to private national companies, and restrictions on private capital, such as local content provision and/or subsidization for poorer regions and groups, among others.
} 
PetroCanada or Electricité de France; or have received vast and ongoing support from the public sector, such as Boeing, Airbus, and Bombardier. ${ }^{16}$

In this article, we build upon Cárdenas et al.'s comprehensive historical review of ISI by creating a statistical comparison of ISI2's performance with that of the current period of neoliberalism. We think a comparison is particularly important because we would like to avoid simply criticizing economic policies in isolation, which is all too easy an exercise. While it is important to recognize that there are differences within the ISI and neoliberal periods, and across countries, each economic policy framework represents a fundamentally shared philosophy towards economic development. Therefore, the more important the question is, what does the historical comparative record tell us about the optimal role of the state and protection for Latin American growth and equity? The answer to this question will give us a better idea of which policies make sense for Latin America given long-term constraints and patterns in economic policy conditions. We create criteria based upon the criticisms, both left and right, of the ISI2 and neoliberal periods, and then add a few additional measures of our own, as demonstrated in Table 1 below. Since Latin American development occurs in a positive historical trajectory in a sense of absolute standards of living, we will be measuring improvement over the period. We define the ISI period as 1950-80, and neoliberalism as 1980-2000. Because consistent data sets are so limited, we rely on descriptive statistics to test whether differences exist between the two periods.

Table 1: Criteria for comparing ISI and neoliberalism

\begin{tabular}{ll}
\hline Criteria for Measurement & Measurement indicators \\
\hline EQUITY & GINI, changes in Living Standards Index \\
\hline Relative income & Changes in GDP \\
\hline Openness/Vulnerability & Changes in investment \\
\hline & Balance of trade \\
\hline Fiscal policy & External debt levels \\
\hline & Volatility of currency value \\
\hline & Government budget deficits/surpluses \\
\hline Other & Indirect/direct tax receipts \\
\hline Industrialization & Inflation \\
\hline
\end{tabular}

Data sources: Thorp and Oxford Latin American Database

${ }^{16}$ Author, 2003. 


\section{MEASURES OF EQUITY}

Though LA is a region known for inequality from its origins (obviously deeper-rooted than ISI), it is difficult to evaluate the effects of specific policies because of the paucity of data. The Gini coefficient is the standard measure for relative income inequality. Unfortunately, there are few consistent databases with Gini statistics. However, Table 2 below shows that according to the limited data available, there is no clear pattern in terms of relative inequality for the major economies in the region. In the cases of Argentina and Chile, inequality increased, both in the initial ISI2 period and during neoliberalism. Brazil increased initially and has remained stable since the ISI2 period. Inequality in Mexico also increased during ISI2's initial phase, and then decreased. There are limited data for Venezuela, but inequality seems to have decreased during the heyday of Andres Pérez's ISI2 policies, but stabilized during neoliberalism.

Table 2: Gini coefficient comparisons over time

\begin{tabular}{lccccccccc}
\hline Country & early 50s & $1960-64$ & $1967-70$ & $1971-74$ & $1977-80$ & $1981-85$ & $1985-90$ & $1990-95$ & Pattern \\
\hline Argentina & 0.37 & 0.41 & 0.41 & 0.42 & 0.46 & & 0.51 & 0.54 & increasing \\
\hline Brazil & & 0.57 & 0.63 & & 0.62 & & 0.64 & & stable \\
\hline Chile & 0.44 & 0.46 & 0.5 & 0.47 & 0.52 & 0.52 & 0.54 & 0.52 & increasing \\
\hline Mexico & 0.59 & 0.61 & 0.59 & & 0.55 & 0.48 & 0.52 & 0.53 & decreasing \\
\hline Venezuela & & & & 0.49 & & 0.39 & 0.41 & 0.4 & decreasing \\
\hline
\end{tabular}

Notes: used national figures for Brazil, Col, CR, Mex, and Ven, rest are urban; chose year for which data exists W/i range for years up to 1980 , then took average for years where mult. yrs. avail.; Peru not avail.

Source: Thorp, 1998

Another common measure of inequality and poverty is the UN Historical Living Standards Index (HLSI). This index assigns weights to GDP per capita, life expectancy, and the adult literacy rate. The historical index looks at changes from the median. I have calculated changes by decade in the HLSI in Table 3.

Table 3: Improvements in standard of living

\begin{tabular}{lcccccc}
\hline Country & $1950-60$ & $1960-70$ & $1970-80$ & $1980-90$ & $1990-95$ & Trend \\
\hline Argentina & $8 \%$ & $16 \%$ & $9 \%$ & $-6 \%$ & $9 \%$ & decreasing \\
\hline Brazil & $40 \%$ & $21 \%$ & $36 \%$ & $4 \%$ & $3 \%$ & decreasing \\
\hline Chile & $18 \%$ & $15 \%$ & $11 \%$ & $10 \%$ & $11 \%$ & decreasing \\
\hline Mexico & $25 \%$ & $24 \%$ & $21 \%$ & $2 \%$ & $1 \%$ & decreasing \\
\hline Peru & $29 \%$ & $22 \%$ & $16 \%$ & $-3 \%$ & $6 \%$ & decreasing \\
\hline Venezuela & $22 \%$ & $17 \%$ & $11 \%$ & $-1 \%$ & $1 \%$ & decreasing \\
\hline
\end{tabular}

Source: Author Calculations fr. Thorp, 360

Notes: $1950=100$, based on changes in UN Human Development Index 
Table 3 shows that standards of living actually declined in every case except Chile (and Mexico where they were stable) in the 1980s, and the rate of improvement has not come close to the levels attained under the ISI period. In sum, the data on inequality show that ISI's record on inequality is at least as good, and probably better, than that of neoliberalism.

We turn to macroeconomic variables, and economists' golden key of economic growth in Table 4.

Table 4: Key economic indicators for LA-ISI vs. Neoliberal period

\begin{tabular}{|c|c|c|c|c|c|c|c|c|c|c|c|}
\hline $\begin{array}{l}\text { Variable } \\
5 \text { year ave) }\end{array}$ & Country & 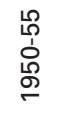 & $\begin{array}{l}\text { ○ } \\
0 \\
0 \\
\circ \\
0\end{array}$ & 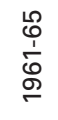 & 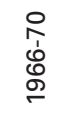 & $\begin{array}{l}\frac{L}{2} \\
\frac{1}{5} \\
\frac{1}{2}\end{array}$ & $\begin{array}{l}0 \\
0 \\
1 \\
0 \\
0 \\
0\end{array}$ & 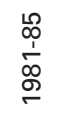 & $\begin{array}{l}\text { ᄋ } \\
\text { ஸे } \\
\text { o } \\
\circ\end{array}$ & 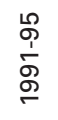 & 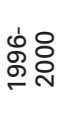 \\
\hline $\begin{array}{l}\text { GDP growth } \\
\text { (\%) }\end{array}$ & Argentina & 3 & 4 & 3 & 5 & 2 & 2 & 1 & 1 & 5 & 2 \\
\hline \multirow[t]{5}{*}{ (up to 1999) } & Brazil & 6 & 8 & 3 & 10 & 10 & 4 & 4 & 1 & 3 & 2 \\
\hline & Chile & 3 & 5 & 5 & 4 & -2 & 8 & 0 & 6 & 7 & 4 \\
\hline & Mexico & 6 & 6 & 8 & 6 & 5 & 7 & 0 & 3 & 2 & 6 \\
\hline & Peru & 6 & 6 & 8 & 6 & 5 & 7 & 0 & 3 & 2 & 6 \\
\hline & Venezuela & 9 & 5 & 7 & 5 & 6 & 2 & 0 & 3 & 2 & 1 \\
\hline \multirow{6}{*}{$\begin{array}{l}\text { Ave govt. } \\
\text { Deficit (\%) }\end{array}$} & Argentina & -51 & -49 & -33 & -20 & -69 & -16 & -26 & -6 & -2 & -17 \\
\hline & Brazil & -15 & -45 & -65 & -20 & -65 & -92 & -13 & -36 & $\mathrm{n} / \mathrm{a}$ & n/a \\
\hline & Chile & -13 & -20 & -27 & -16 & -11 & 5 & -10 & -3 & 8 & 3 \\
\hline & Mexico & -11 & -32 & -61 & -27 & -24 & -17 & -50 & -52 & 1 & -9 \\
\hline & Peru & -4 & -6 & -9 & -21 & -25 & -29 & -9 & -43 & -17 & -8 \\
\hline & Venezuela & 2 & -2 & -7 & 2 & 23 & 8 & 13 & -12 & -4 & -3 \\
\hline \multirow{6}{*}{$\begin{array}{l}\text { Gross } \\
\text { Domestic } \\
\text { Fixed } \\
\text { Investment } \\
(\%)\end{array}$} & Argentina & 16 & 17 & 23 & 20 & 21 & 25 & 21 & 17 & 18 & 18 \\
\hline & Brazil & 19 & 17 & 15 & 18 & 24 & 22 & 20 & 23 & 19 & 19 \\
\hline & Chile & 20 & 21 & 22 & 20 & 16 & 14 & 15 & 21 & 23 & 24 \\
\hline & Mexico & 16 & 17 & 17 & 19 & 20 & 22 & 21 & 19 & 19 & 20 \\
\hline & Peru & 19 & 22 & 18 & 14 & 14 & 18 & 24 & 18 & 19 & 22 \\
\hline & Venezuela & 34 & 29 & 18 & 21 & 24 & 34 & 20 & 19 & 19 & 17 \\
\hline \multirow{4}{*}{$\begin{array}{l}\text { External } \\
\text { Debt/GDP } \\
(\%)\end{array}$} & Argentina & & & & 11 & 15 & 18 & 43 & 56 & 32 & 48 \\
\hline & Brazil & & & & & 19 & 26 & 44 & 35 & 29 & 33 \\
\hline & Chile & & & & & 41 & 37 & 96 & 75 & 40 & 47 \\
\hline & Mexico & & & & & 19 & 32 & 60 & 60 & 39 & 37 \\
\hline
\end{tabular}




\begin{tabular}{|c|c|c|c|c|c|c|c|c|c|c|c|}
\hline & Peru & & & & & 45 & 65 & 54 & 54 & 60 & 55 \\
\hline & Venezuela & & & & & 14 & 37 & 55 & 66 & 60 & 39 \\
\hline \multirow{6}{*}{$\begin{array}{l}\text { Manuf. } \\
\text { Value } \\
\text { Added } \\
\text { (\% GDP) }\end{array}$} & Argentina & 24 & 26 & 27 & 29 & 32 & 30 & 25 & 25 & 24 & 22 \\
\hline & Brazil & 21 & 25 & 27 & 27 & 30 & 30 & 27 & 26 & 24 & 23 \\
\hline & Chile & 24 & 25 & 27 & 28 & 27 & 23 & 21 & 22 & 21 & 19 \\
\hline & Mexico & 19 & 19 & 20 & 23 & 24 & 24 & 24 & 24 & 24 & 27 \\
\hline & Peru & 15 & 16 & 18 & 20 & 22 & 21 & 18 & 19 & 19 & 18 \\
\hline & Venezuela & 12 & 14 & 14 & 15 & 15 & 16 & 18 & 19 & 18 & 17 \\
\hline \multirow{3}{*}{$\begin{array}{l}\text { Standard } \\
\text { Deviation }\end{array}$} & & 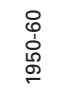 & 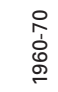 & 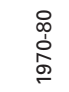 & $\begin{array}{l}\text { ○ } \\
\text { के } \\
\text { o } \\
\text { ○ }\end{array}$ & ஓ̊. & & & & & \\
\hline & Argentina & 28 & 118 & 636 & 7684 & 3095 & & & & & \\
\hline & Brazil & 56 & 805 & 14 & 1854 & 26498 & & & & & \\
\hline \multirow{2}{*}{$\begin{array}{l}\text { Deviation } \\
\text { of } \\
\text { Nominal }\end{array}$} & Chile & 317 & 3 & 1465 & 98 & 67 & & & & & \\
\hline & Mexico & 2 & 0 & 5 & 1094 & 1388 & & & & & \\
\hline \multirow{2}{*}{$\begin{array}{l}\text { Exchange } \\
\text { Rate }\end{array}$} & Peru & 4 & 5 & 89 & 56380 & 56649 & & & & & \\
\hline & Venezuela & 0 & 1 & 0 & 14 & 246 & & & & & \\
\hline
\end{tabular}

Source: Oxford Latin American Database

Notes: Author Calculations from GDP 1970 \$PPP; SD= standard dev. of nominal exchange rate; govt. deficit is LCU (rev-expenditures)/revenues; GDFI (\% of GDP); External Debt, current \$, Arg fr. 1967-70, Chile 1996-99; MVA/GDP based on LCU current

We do not need advanced statistical tests to see Table 4 demonstrating that the ISI2 period had markedly higher and more consistent growth rates across the region, except for Chile (which began neoliberalism in 1976). This Table underscores the moniker "lost" for the 1980s decade associated with skyrocketing external debt, yet it shows that growth has not really recovered in most of the region. It is important to note that poverty indices for access to education and health care have continued to improve over time and across economic periods in absolute terms. It bears acknowledging that one would expect marginal gains to become more difficult as higher levels are achieved, also depending on overall population growth. Since we don't know how to separate out difficulties of a particular period from the overall trajectory, a regression or panel data analysis will not answer our questions. Table 4 also demonstrates a reduction in manufacturing value added, a worrying sign for the goal of increasing local production of goods, even if for export. With local production comes local employment and a reduction in inequality. We also see a higher standard deviation of the nominal exchange rate and external debt increase throughout the neoliberal period, before dipping slightly in the last five years, indicating increased volatility, 
rather than stability has been the case in macroeconomics, as we have seen in the financial crises in Chile, 1982, Mexico, 1992, Brazil, 1999, and Argentina, 2000. There appears to be no clear regional pattern for gross domestic fixed investment for the region, which was the key gain expected by leaders in switching to neoliberal policies. The one area of marked improvement during the neoliberal period is a reduction in the government budget deficit, which arguably also increased unemployment, though unfortunately there are no consistent data through which test this. More worrying still is the inability of LA countries to raise taxes being heralded across the region, including the recent failures of Argentina and Mexico to pass vaunted fiscal reform packages. One interpretation of these trends could thus be that as the state has reduced its fiscal role and liberalized the economy, private foreign capital, both direct and portfolio's, has stepped in to maintain fixed investment at the same rate. Even if true, foreign capital has yielded neither the same growth rates nor the same increase in manufacturing value added.

\section{CONCLUSION}

We have demonstrated in this research note that the depiction of the ISI2 period as one of utter failure by both dependistas and neoliberals is empirically false. While there were obvious problems, such as agricultural productivity and macroeconomic volatility, an objective assessment could not reach the conclusion that state-led industrialization is a clear dead end and neoliberalism the answer. On the contrary, it is the sudden increase in US interest rates in the early 1980 s that forces LA countries to abandon the steady growth and industrial progress of the ISI2 and embrace neoliberalism as a forced form of prolonged "shock therapy." Thus, LA governments did not simply see "the light" of neoliberal arguments about the sanctity of the market. They were forced into such conclusions by the circumstances of financial capital on the one hand, and the hopefulness of Chilean progress on the other. However, as is well documented, the Chilean model has also meant increasing inequality and a lack of shared progress. ${ }^{17}$ Moreover, the Chilean model has not yet been reproduced in any other LA country seeking macroeconomic stability. Neoliberal economists, continuing to ignore any recognition of political factors, will simply continue to berate LA governments for not following through on the crucial " 2 nd generation" reforms needed for a neoliberal system to reform itself. ${ }^{18}$

This brings us to our present crucial point in history, where LA may again have some room for maneuver. At the present historical juncture, it seems likely that LA will continue to experiment with modifications of neoliberalism, attempting to drive a harder bargain with external capital and marginally improve

\footnotetext{
${ }^{17}$ Oppenheim (1998).

${ }^{18} \mathrm{On} 2^{\text {nd }}$ generation reforms, see Anne O. Krueger (2000).
} 
social welfare systems, without fundamentally changing course, such as has been the case of Lagos in Chile, Kirchner in Argentina, and Lula in Brazil. On the other, where the lack of growth and stability as well as relative inequality continue to be problems, we can see desires for the state to revive its previous leadership role. We see this not only in Venezuela, but also in the ousting of the Bolivian President Gónzalez Sanchez de Lozada over privatization and export of natural gas; and Evo Morales' rise on the platform of nationalism and ethnic and regional redistribution; and Lula in his leadership to block negotiations at the Free Trade Area of the Americas and the World Trade Organization, which reverberate with the anti-imperialist foundation of Latin American intellectual and cultural discourse. Even in Mexico, the improved status of the PRD (Partido Revolucionario Democrático) suggests a shift to the left. The real conundrum for LA is one that predates ISI and neoliberalism and points to the deeper roots of the economic problems that this article suggests, including endemic inequality, poorly functioning institutions and lack of rule of law, and how to alleviate external dependence and control with the need for transformation of economic, political, and social structures to a more productive state. Undoubtedly, neoliberalism will be defended by the externally-oriented capitalist classes who have benefited from renewed export drives, but as with the case of ISI, the limits of the spread of growth in the short-run lays the seeds for a counter-revolution.

In sum, following the descriptive conclusions of Cárdenas, Ocampo, and Thorp (2000), we see that the ISI period was one of macroeconomic volatility and income inequality, but also great industrial progress. Could such progress have led to a more sustainable model or form the basis for a revived version? Jorge Katz argues that the macroeconomic instability, uncertainty, lack of savings, investment, and entrepreneurial spirit, and the unwillingness to promote exports mean that long-term performance was bound to be sub-par compared to Southeast Asian counterparts. ${ }^{19}$ Katz argues that while labor productivity and export performance have improved in the current neoliberal period, the results are concentrated mainly in "large domestic conglomerates and local subsidiaries of (MNCs) in raw material-processing industries and in the automotive sector..." On the other hand, "hundreds of firms producing garments, leather goods, furniture, and machine closed down during the 1990s." Small and medium enterprises have suffered the most in recent years. Katz concludes that new forms of government intervention are needed to improve the distribution of the benefits from recent changes. (311-12)

The point of this note is not that ISI was not without its flaws, but rather that the lessons drawn from the period are completely incorrect. The macroeconomic and external debt crises of the 1980s would have wracked even the most erstwhile liberalized enterprises, as we have seen with the widespread failure of privatized and competitive firms across the board in neoliberal Argentina

${ }^{19}$ Jorge Katz (2000, pg. 309). 
in the late 1990s. The real lessons, as argued in detail elsewhere (Hira, forthcoming), are that macroeconomic stability and export promotion, (fr. neoliberalism), and industrial promotion (fr. ISI) and attention to income inequality (through local value-added employment growth and access to education and health care) are not incompatible, rather they are a necessary combination for development for the long-term benefit of the diverse groups of LA.

\section{REFERENCES}

BAER, WERNER (1972) "Import Substitution and Industrialization in Latin America: Experiences and Interpretations," Latin American Research Review. 7,1(Spring): 95-122.

CARDENAS, ENRIQUE, JOSE ANTONIO OCAMPO AND ROSEMARY THORP (2000) An Economic History of Twentieth Century Latin America. NY: Palgrave.

CARDOSO, FERNANDO HENRIQUE (1977) “The Originality of a Copy: CEPAL and the Idea of Development," CEPAL REVIEW 4 (2 $2^{\text {nd }}$ half).

EDWARDS, SEBASTIAN (@) Crisis and Reform in Latin America: From Despair to Hope. NY: Oxford University Press for the World Bank.

ELLNER, STEVE (2004) "Leftist Goals and the Debate over Neo-liberal Strategy in Latin America," Science and Society. 68,1: 10-32.

FAJNZYLBER, FERNANDO (1990) Unavoidable Industrial Restructuring in Latin America. Durham: Duke U. Press.

GROSFOGUEL, RAMON (2000) "Developmentalism, Modernity, and Dependency Theory in Latin America," Nepantla: Views from the South. 1,2: 347-374.

HIRA, ANIL (1998) Ideas and Economic Policy in Latin America: Regional, National, and Organizational Case Studies. Westport: Greenwood.

HIRA, ANIL (2003) "Regulatory Games States Play: Managing Globalization Through Sectoral Policy," c.4, 41-58 in Marjorie Griffin Cohen and Stephen McBride, eds. Global Turbulence: Social Activists' and State Responses to Globalization. Burlington: Ashgate

HIRA, ANIL (under review) The New Path to Growth and Equity: How Industrial Policy Succeeded in East Asia and Can Work in Latin America, seeking publisher

HIRSCHMAN, ALBERT O. (1968) “The Political Economy of Import-Substituting Industrialization in Latin America," The Quarterly Journal of Economics. 82, 1 (Feb.): 1-32.

IGLESIAS, ENRIQUE V. (1992) Reflections on Economic Development: Toward A New Latin American Consensus. Washington: Inter-American Development Bank.

KATZ, JORGE (2000) "The Dynamics of Technological Learning during the Import-Substitution Period and Recent Structural Changes in the Industrial Sector of Argentina, Brazil, and Mexico," pp. 307-334 in Linsu Kim and Richard R. Nelson, eds., Technology, Learning and Innovation: Experiences of Newly Industrializing Economies. NY: Cambridge U. Press.

KRUEGER, ANNE O., (2000) Economic Policy Reform: The Second Stage. Chicago: The University of Chicago Press.

O'DONNELL, GUILLERMO "Reflections on the Patterns of Change of the BureaucraticAuthoritarian State," Latin American Research Review. 13,1: 3-38.

OPPENHEIM, LOIS HECHT (1998) Democracy, Authoritarianism, and the Search for Development, $2^{\text {nd }}$ ed. Boulder: Westview.

TAYLOR, LANCE, (1999) After Neoliberalism: What Next for Latin America?. Ann Arbor: The U. of Michigan Press.

THIESENHUSEN, WILLIAM C. (1972) “A Suggested Policy for Industrial Reinvigoration in Latin America," Journal of Latin American Studies. 4,1(May): 85-104.

THORP, ROSEMARY (1998) Progress, Poverty and Exclusion: An Economic History of Latin America in the $20^{\text {th }}$ Century. Washington: IADB.

WEAVER, FREDERICK STIRTON (2000) Latin America in the World Economy: Mercantile Colonialism to Global Capitalism. Boulder: Westview. 